\title{
Corrigendum: Critical analysis of the role of innovative capabilities on firm performance: Evidence from the University of Cape Coast administration in Ghana
}

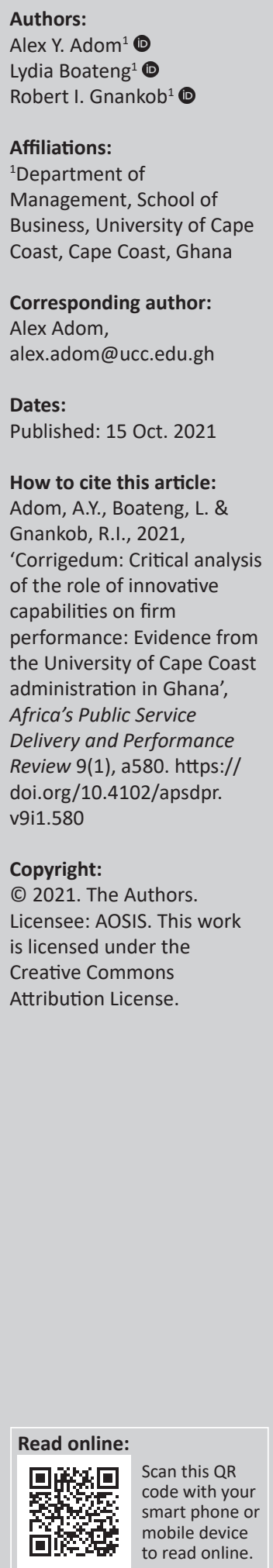

In the version of the article initially published, Adom, A.Y., Boateng, L. \& Gnankob, R., 2019, 'Critical analysis of the role of innovative capabilities on firm performance: Evidence from the University of Cape Coast administration in Ghana', Africa's Public Service Delivery and Performance Review 7(1), a256. https://doi.org/10.4102/apsdpr.v7i1.256, the name of the third author was given incorrectly. The correct name should be Robert I. Gnankob instead of Robert Gnankob in the 'Authors' and 'How to cite this article' sections.

This correction does not alter the study's findings of significance or overall interpretation of the study's results. The authors apologise for any inconvenience caused. 


\section{Critical analysis of the role of innovative capabilities on firm performance: Evidence from the University of Cape Coast administration in Ghana}

\begin{tabular}{|c|c|}
\hline \multicolumn{2}{|c|}{$\begin{array}{l}\text { Authors: } \\
\text { Alex Y. Adom }{ }^{1} \text { (D) } \\
\text { Lydia Boateng }^{1} \text { (D) } \\
\text { Robert Gnankob }^{1} \text { (1) }\end{array}$} \\
\hline \multicolumn{2}{|c|}{$\begin{array}{l}\text { Affiliations: } \\
{ }^{1} \text { Department of } \\
\text { Management, School of } \\
\text { Business, University of Cape } \\
\text { Coast, Cape Coast, Ghana }\end{array}$} \\
\hline \multicolumn{2}{|c|}{$\begin{array}{l}\text { Corresponding author: } \\
\text { Alex Adom, } \\
\text { alex.adom@ucc.edu.gh }\end{array}$} \\
\hline \multicolumn{2}{|c|}{$\begin{array}{l}\text { Dates: } \\
\text { Received: } 10 \text { Jan. } 2019 \\
\text { Accepted: } 29 \text { July } 2019 \\
\text { Published: } 06 \text { Dec. } 2019\end{array}$} \\
\hline \multicolumn{2}{|c|}{$\begin{array}{l}\text { How to cite this article: } \\
\text { Adom, A.Y., Boateng, L. \& } \\
\text { Gnankob, R., 2019, 'Critical } \\
\text { analysis of the role of } \\
\text { innovative capabilities on } \\
\text { firm performance: Evidence } \\
\text { from the University of } \\
\text { Cape Coast administration in } \\
\text { Ghana', Africa's Public Service } \\
\text { Delivery and Performance } \\
\text { Review 7(1), a256. https:// } \\
\text { doi.org/10.4102/apsdpr. } \\
\text { v7i1.256 }\end{array}$} \\
\hline \multicolumn{2}{|c|}{$\begin{array}{l}\text { Copyright: } \\
\text { (C) 2019. The Authors. } \\
\text { Licensee: AOSIS. This wor } \\
\text { is licensed under the } \\
\text { Creative Commons } \\
\text { Attribution License. }\end{array}$} \\
\hline \multicolumn{2}{|l|}{ Read online: } \\
\hline 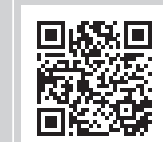 & $\begin{array}{l}\text { Scan this QR } \\
\text { code with your } \\
\text { smart phone or } \\
\text { mobile device } \\
\text { to read online. }\end{array}$ \\
\hline
\end{tabular}

Background: The increasingly competitive business environment has made it imperative for organisations to put in place systems and processes that will guarantee appreciable firm performance in the interest of its stakeholders. To this end, several solutions have been developed to ensure that desired firm outcomes are achieved despite the dynamics of competition. However, critical review of extant literature reported mixed results on the innovative capabilities of firms and their performance nexus. Therefore, this article explored the role of innovative capabilities on the performance of firms with the University of Cape Coast as a case study.

Aim: This paper explored the role of innovative capabilities on the performance of firms with the evidence from the University of Cape Coast.

Setting: The research was carried out in Ghana to assess innovative capabilities and performance relationship among institutions of higher learning with evidence from the University of Cape Coast.

Methods: Using a descriptive research design, the study collected data from 250 administrative staff in the university of Cape Coast. The findings of the study confirmed that the administrative staffs of the University of Cape Coast have embraced innovation at different levels of operations.

Results: The findings indicate that innovation in the organisation is able to promote high team spirits, risk taking, productivity, low resistance to change, competitive advantage, increase market share, increase productivity among staffs, growth and profitability of educational institutions, creates loyalty towards the institution's services, and makes teaching and learning convenient.

Conclusion: It was concluded that there have been some innovations in University of Cape Coast and so much of such innovations would make teaching and learning more convenient, lead to higher competitive advantage and market share and boosting overall performance.

Keywords: Innovative; capabilities; firm; performance; University of Cape Coast; UCC.

\section{Introduction}

The increasingly competitive business environment has made it imperative for organisations to put in place systems and processes that will guarantee appreciable firm performance in the interest of its stakeholders. To this end, several solutions have been developed to ensure that desired firm outcomes are achieved despite the dynamics of competition. In today's business environment, organisations keep evolving ways of outwitting one another in the marketplace in order to remain competitive and achieve strategic goals. One such strategy is innovation. According to Odumeru (2013:18), '[i]nnovation is one concept that has gained enormous popularity in both business research and practice'. Research indicates that firm performance is influenced by innovation (DuránVázquez, Lorenzo-Valdés \& Moreno-Quezada 2012; Likar, Koper \& Fatur 2014; Nybakk \& Jenssen 2012; Oke, Walumbwa \& Myers 2012; Yen 2013). Undertaking research on these constructs is important for organisations as managers should be aware of the impact of different variables on firm performance in order to manage them in an effective manner (Bigliardi 2013; Ndregjoni \& Elmazi 2012). Firm performance is an important indicator of firm success (Stegerean \& Gavrea 2010). Apart from firm performance, firm success also relates to employee skills levels, personnel development, quality of strategic planning and the ability to understand and adapt to the nature and dynamics of the business environment (Zhou, Yim \& Tse 2005). However, firm performance is arguably the most important indicator of firm success and one of the most important variables in management research (Stegerean \& Gavrea 2010). 
This research will help determine how innovative capabilities in the administrative sector have improved students' performance. It will also serve as a reference for future studies on similar topics. The research work looks at how performance outcomes of organisations have been influenced by their innovation strategies, drawing evidence from literatures. Therefore, the following hypothesis was developed to help achieve the objectives of the study: there is a positive relationship between innovative capabilities and performance of University of Cape Coast (UCC)'s administration.

\section{Literature review}

This section discusses the issues of scholarly perspectives on innovative capabilities and firm performance nexus. It presents the theory that underpins the study and the general overview of the constructs under study.

\section{Theoretical review}

Many theories underpin the concept of innovation and innovative capabilities. This study utilised resource-based theory, which examines the relationship between internal possessions of the firm and its performance. Scholars of the theory, such as Lippman and Rumelt (1982), Wernerfelt (1984), Barney (1986) and Peteraf (1993) placed an emphasis on the need for an organisation to continuously improve upon its resources within. These resources have been classified as physical, human and firm resources. Physical resources include all plant and equipment, location, technology, raw materials and machines; human resources include all employees, training, experience, intelligence, knowledge, skills and abilities; and firm resources include firm structure, planning processes, information systems, patents, trademarks, copyrights and databases (Hesterly \& Barney 2008).

Furthermore, Akio (2005), Das and Teng (2000), Powell (2001) and Barney, Ketchen and Wright (2011) pointed out that an organisation's success is linked to how valuable its internal resources are relative to other firms. They suggested that these resources must be rare, not easy to be copied and nonsubstitutable. When these resources are effectively utilised, they result in competitive advantage and high and sustained levels of firm performance (Walker 2004 cited in Bowman and Ambrosini 2003). This theory is relevant to this study because it gives a clear picture of what improvements firms should carry out to beat competition and attract performance.

\section{Concept of innovation}

Innovation is the most fundamental source for a firm's success and survival in such a competitive complex and intellectual environment (Abbing 2010; Cho \& Pucik 2005). BusinessDictionary.com defines innovation as the process of translating an idea or invention into a good or service that creates value or for which customers will pay. Innovation is a strategic tool for firms to survive and gain competitive advantages in the global marketplace (Karabulut 2015). Innovative firms can improve their performances, beat their competitors and provide value to their stakeholders. To be called an innovation, an idea must be replicable at an economical cost and must satisfy a specific need. Innovation involves deliberate application of information, imagination and initiative in deriving greater or different values from resources and includes all processes by which new ideas are generated and converted into useful products. In business, innovation often results when ideas are applied by the company in order to further satisfy the needs and expectations of the customers.

Innovation is a source of competitive advantage for a firm (Zawislak et al. 2012). According to Oslo Manual on Organisation for Economic Co-operation and Development (OECD 2005:46), an innovation is:

... the implementation of a new or significantly improved product (good or service), or process, a new marketing method, or a new firm method in business practices, workplace organisation or external relations.

Rajapathirana and Hui (2018:45) opined that innovation is no longer just a matter of competitive advantage, but a matter of survival'. Therefore, the organisation's ability to understand and implement the changing dimensions of innovations offers it the opportunity to integrate its competences for a better competitive advantage.

In the area of strategic management, it is argued that company sustainability can only be realised by discerning in advance and finding new answers, which include the development of the firm as well as modifying old and developing new products. Strategic management theory also posits that innovation is the primary means by which organizations adjust to their environment supra system (Mintzberg 2008). Prior researchers have put this concept into two categories as it being 'evolutionary or revolutionary' (Serdyukov 2017), 'sustaining or disruptive' (Christensen \& Overdorf 2000; Yu \& Hang 2010). While evolutionary innovations lead to continued improvement, revolutionary innovations bring about a comprehensive change, entirely overhauling and/or replacing the old with the new, often in a short time period. Furthermore, while sustaining innovation spreads the current dimensions of performance (e.g. continuous improvement of the curriculum), disrupting innovation, such as a national reform, radically changes the whole field.

Innovation does not only apply to products, but also play a great role in the education sector (Huang et al. 2012):

It is widely believed that countries' social and economic wellbeing will depend to an ever-greater extent on the quality of their citizens' education: the emergence of the so-called 'knowledge society', the transformation of information and the media, and increasing specialization on the part of organizations all call for high skill profiles and levels of knowledge. Today's education systems are required to be both effective and efficient, or in other words, to reach the goals set for them while making the best use of available resources. (Cornali 2012:255).

The OECD (2005:47) report indicated that the pressure to increase equity and improve educational outcomes for 
students is growing around the world'. In the same vein, Serdyukov (2017) reported that in the USA, fundamental gravity to innovate comes from political, economic, demographic and technological forces that emanated from both inside and outside the nation.

The Oslo Manual (OECD 2005:47) 'classified innovation as product innovation, marketing innovation, firm innovation and process innovation'.

\section{Product innovation}

Karabulut (2015) defines product innovation as the development of new products, changes in design of established products, or use of new materials or components in manufacture of established products. In other words, anything which is new to the business and its product range is counted as innovation, even if similar products are available elsewhere or if the change is an incremental one. This type of innovation can be recognised easily by stakeholders of a firm because it usually requires continuous research and development to be competitive in the market. It is 'the introduction of a good or service that is new or significantly improved with respect to its characteristics or intended uses' (OECD 2005:48). This includes significant improvements in technical specifications, components and materials, incorporated software, user-friendliness or other functional characteristics (Karabulut 2015). Günay (2007) posits that a new product can be developed by combining current technologies and using them differently or using radical technologies. Deming (1986) is of the view that firms have to carefully recognise the needs of customers and make products and services to create better lives to them in order to survive in the long term.

\section{Process innovation}

According to Rajapathirana and Hui (2018), process innovation is the application of new or significantly improved production or delivery methods. It may be considered changes in tools, human capital and working methods, or a combination of these, such as installation of new or improved software to speed up the claim settlement process and policy issuing (OECD 2005). In the view of Karabulut (2015:1357), process innovation serves as a tool to improve firm productivity. A firm may 'adopt new technologies, buy new machineries, train their employees and reorganize their processes to make a process innovation'. Atalay, Anafata and Sarvan (2013) defined process innovation to include significant changes in techniques, equipment and/or software (e.g. installation of new or improved manufacturing technology, such as automation equipment or real-time sensors that can adjust processes, computer-aided product development). Firms are placed at an advantage race if their processes in the design of a product or service, the brand and, the kind of information technology they use are consistently changing relative to their competitors.

\section{Marketing innovation}

Marketing innovation is seen as the implementation of a new marketing method involving significant changes in product design or packaging, product placement, product promotion or pricing (Atalay et al. 2013). The Oslo Manual (OECD 2005:49) defines a marketing innovation as 'the implementation of a new marketing method involving significant changes in product design or packaging, product placement, product promotion or pricing'. It highlights that a marketing innovation may open new markets, address customer needs and reposition products in the market to increase sales. Marketing innovations are aimed at better addressing customer needs, opening up new markets or newly positioning a firm's product with the objective of increasing the firm's sales.

\section{Organisational innovation}

A firm's innovation is the execution of the different firm procedures in the organisation's practices, workplace, business, or outside relations (Meroño-Cerdan \& LópezNicolas 2013). Firm innovation is like outsourcing, partnership, subcontract plus organisation work practice such as quality management, reengineering and lean management (Karim Suhag et al. 2017). Karabulut (2015) believes that 'organisational innovation expands the capabilities and vision of a firm, improves employee satisfaction, and leads to firm transformation'. Gümüş and Gümüş (2015) are also of the view that a firm innovation can be related to new communication and cost system.

Firm innovation can lead to improvement in the performance of the firm by reducing administrative and transaction cost, while also increasing the workplace satisfaction (Rajapathirana \& Hui 2017).

\section{Innovation capabilities}

The term 'innovation capability' is understood in varied and diffuse forms in the literature. Scholars have sparked debates on the appropriate definition of innovation capabilities. Lau, Yam and Tang (2010) stressed that innovation capability facilitates a firm in applying appropriate process technologies to develop new products in order to meet the market needs and eliminate competitive threats. Narcizo, Canen and Tammela (2013) stated that there are many definitions for it, which has generated divergence both about its proper conceptualisation and the contexts in which it should be employed. A firm's innovation capability can be understood as the potential to innovate (Saunila, Pekkola \& Ukko 2014). Lerro, Linzalone and Schiuma (2009) defined it as the ability to continuously transform knowledge and ideas into new products, processes and systems for the benefit of the firm and its stakeholders. It has been expounded by Lawson and Samson (2001) that innovation capabilities are the so-called higher-order capabilities, that is, the ability to mould and manage multiple capabilities.

Organisations possessing this innovation capability have the ability to integrate key capabilities and resources of their firm to successfully stimulate innovation. Innovation capability is a collaborative environment that allows customers, suppliers, employees and other stakeholders to collaborate on innovation where appropriate. A company's 
innovation capability can be described at several different levels and from several different perspectives (Olsson et al. 2010). Innovative capability can be described as an important factor that facilitates an innovative firm culture, the characteristics of internal promoting activities and the capabilities of understanding and responding appropriately to the external environment (Akman \& Yilmaz 2008).

Assink (2006) posits that innovative capability is an internal driving energy to generate and explores radical new ideas and concepts, to experiment with solutions for potential opportunity patterns detected in the market's white space and to develop them into marketable and effective innovations, leveraging internal and external resources and competencies.

In this article, innovation capabilities can be seen as the shared efforts of the functions of an organisation to constantly and effectively monitor its available resources and competences while exploring other opportunities to capture success. To fully utilise innovative capabilities there should be a synergy among the functional areas of the firm in order to explore potential opportunities in the external environment. Gor, Mummassabba and Muturi (2015) have identified that superior innovation capability tends to implement and develop new product varieties to the existing product portfolio. It helps to shape up and manage multiple capabilities of the firm for supporting to integrating capabilities and stimulus into innovation successfully (Lawson \& Samson 2001).

\section{Firm performance}

Firm performance is a multidimensional concept whose indicators can be departmental, such as pertaining to production, finance or marketing (Sohn et al. 2007), or consequential such as pertaining to growth and profit (Wolff \& Pett 2006). Firm performance includes real productivity or outcome of a business that is calculated in opposite to its planned productivity or targets and aims (karim Suhag et al. 2017). Firm performance has been defined as the capability of a firm to accomplish its goals and objectives with the help of talented administration, good governance and a constant rededication to accomplish business objectives (Karim Suhag et al. 2017). Firm performance is the outcome achieved in meeting internal and external goals of a firm (Wei, Liu \& Herndon 2011). It is a desirable outcome an organisation derives from its strategic efforts.

\section{Empirical relationship innovation capabilities and firm performance}

Innovativeness is an important determinant of an organisation's performance (Calantone, Cavusgil \& Zhao 2002; Hult, Hurley \& Knight 2004). Thus, firm performance can be improved through technical and administrative innovation besides other factors (Montes, Moreno \& Morales 2005). Previous research has studied the effects of innovations and innovativeness on firm performance (Adriansyah \& Afiff 2015; Bowen, Rostami \& Steel 2010; Calantone et al. 2002;
Cainelli, Evangelista \& Savona 2004; Gunday et al. 2011; Keskin 2006).

Atalay et al. (2013) conducted a study on top level managers of 113 firms operating in the automotive supplier industry to determine the relationships between innovation and firm performance and found that product and process innovation had significant and positive impacts on firm performance. Karim Suhag et al. (2017) examined the relationship between innovation and firm performance in the telecommunication sector. They used process innovation, product innovation and firm innovation as independent variables and data from a questionnaire administered to 200 employees were analysed through the SPSS v.20 software. Their study results showed that product innovation, process innovation and firm innovation have a positive impact on organisational performance. Furthermore, Saunila et al.'s (2013) study on a total of 311 data from a sample of 2400 randomly selected Small and Medium-Sized Enterprises (SMEs) revealed that there was significant and positive relationship between innovation capability and firm performance. Rajapathirana and Hui (2017) concluded that a company with higher innovation capabilities has influenced positively and very strongly. Alam (2006) found that a firm's innovation capabilities have a greater impact on the overall performance.

This article would further examine the relationship between innovation capabilities and organisational performance with special reference to UCC administrative staff.

\section{Research methodology Research design}

The study adopted a descriptive design in examining the role of innovative capabilities on performance in the educational sector. The use of this research design allows the researchers to use both quantitative and qualitative methods in the analysis. The researchers employed a self-administered questionnaire method to collect quantitative data.

\section{Sample size and sampling procedure}

The researchers used the 'Survey Monkey' software to determine the sample size. It required that the researchers fill in the population, confidence interval and margin of error so that the sample size will be determined automatically. The researchers estimated the confidence interval to be $95 \%$ and the margin of error to be $5 \%$ with a population of 3558 . This gave a sample size of 347 . The researchers adopted a convenient sampling technique that was used to retrieve information from staff members. The convenience sampling method is a simple approach where a sample is selected according to the convenience of the researchers (Saunders et al. 2016).

\section{Research instrument}

This research seeks to employ a semi-structured questionnaire guide where both open and closed questions will be administered. As Kothari (2004) observed, questionnaires are 
more objective than interviews because they gather responses in a standardised way. They are also easy to use when collecting information. Both closed-ended and open-ended questions were used. The open-ended items permitted a greater depth of response. The closed items captured personal details and attitude scales. This simply means the types of questions to be passed are open, probing and specific or closed questions.

\section{Data analysis}

Data were analysed using tables. The study used descriptive and inference analysis. Data gathered were fed into the SPSS program using percentages and frequencies. Inferences were drawn from the tables through the use of frequencies. The data were also described in order to get a fair visual understanding of the responses from the respondents in the study.

\section{Ethical consideration}

All the ethical principles in research were strictly adhered to in this study.

\section{Results and discussion}

\section{Assessing the performance of University of Cape Coast Administration using product/ service innovation}

Respondents were asked about the priority for developing new products and services to students. Table 1 shows that the priority for new product development has been positive and effective. One hundred and seventeen (46.8\%) respondents

TABLE 1: Priority for developing new products and services to students.

\begin{tabular}{lcc}
\hline Responses & Frequency & $\mathbf{\%}$ \\
\hline Very poor & 7 & 2.8 \\
Poor & 8 & 3.2 \\
Neutral & 43 & 17.2 \\
Good & 117 & 46.8 \\
Very good & 74 & 29.6 \\
Sub-total & 249 & 99.6 \\
Missing system & 1 & 0.4 \\
\hline Total & $\mathbf{2 5 0}$ & $\mathbf{1 0 0 . 0}$ \\
\hline
\end{tabular}

TABLE 2: Priority for satisfying students with added products and services.

\begin{tabular}{lcc}
\hline Responses & Frequency & $\mathbf{\%}$ \\
\hline Very poor & 5 & 2.0 \\
Poor & 11 & 4.4 \\
Neutral & 26 & 10.4 \\
Good & 124 & 49.6 \\
Very good & 80 & 32.0 \\
Sub-total & 246 & 98.4 \\
Missing system & 4 & 1.6 \\
\hline Total & $\mathbf{2 5 0}$ & $\mathbf{1 0 0 . 0}$
\end{tabular}

said the priority for new products and services development is good, $74(29.6 \%)$ said it is very good, $43(17.2 \%)$ respondents were indifferent, $8(3.2 \%)$ said it is poor, $7(2.8 \%)$ said it is very poor, with only $1(0.4 \%)$ giving no response to the question.

The analysis here is that on the whole the priority for developing new products and services for stakeholders has been effective and positive, signifying the need for more development of new products and services.

The respondents were asked about the priority for satisfying students with added product and services. Table 2 shows that the priority for satisfying students with added products or services has been positive and effective. One hundred and twenty-four $(49.6 \%)$ respondents said the priority for satisfying students with added services is good, 80 (32\%) said it is very good, $26(10.4 \%)$ respondents said it is neutral, 11 $(4.4 \%)$ said it is poor and $5(2 \%)$ said it is very poor, with only $4(1.6 \%)$ giving no response to the question. The analysis shows that the priority for satisfying students with added services has been effective and positive and therefore should be encouraged.

\section{Assessing the performance of University of Cape Coast Administration using process innovation}

The researchers asked four questions on the process innovation to examine its impact on the performance of the institution. The results are presented in Table 3 . Regarding the question of the management's commitment to fast and non-bureaucratic processes, 90 respondents said management's commitment is good, 60 said it is very good, 56 were neutral, 34 said commitment is poor and 9 said it is very poor, with only 1 respondent giving no response to the question. This means that a good number of respondents support the view that management is committed to fast and non-bureaucratic processes. Also, on the question of the administration using a decentralised decision-making approach, 100 respondents said that decentralised decisionmaking approach is good, 51 said it is very good, 50 respondents remained neutral, 31 said it is poor and 13 said it is very poor, with 5 respondents giving no response to the question. With a large number of the respondents giving positive responses, it is therefore clear that the administration uses a decentralised decision-making approach.

Furthermore, on the topic of whether the administration supports idea generation and experimentation among staff, 132 respondents said that it is good, 56 said it is very good, 41 remained neutral, 12 said management support is poor and 8 said the support to idea generation is very poor, with only 1 respondent giving no response to the question. This

TABLE 3: Using only frequencies.

\begin{tabular}{|c|c|c|c|c|c|c|c|c|}
\hline Descriptions of variable & Very poor & Poor & Neutral & Good & Very good & Total & Missing system & Total \\
\hline Commitment to fast and non-bureaucratic processes & 9 & 34 & 56 & 90 & 60 & 249 & 1 & 250 \\
\hline Using decentralised decision-making approach & 13 & 31 & 50 & 100 & 51 & 245 & 5 & 250 \\
\hline Support for idea generation and experimentation among staff & 8 & 12 & 41 & 132 & 56 & 249 & 1 & 250 \\
\hline Reward for risk taking and action by staff & 9 & 22 & 64 & 84 & 69 & 248 & 2 & 250 \\
\hline
\end{tabular}


analysis shows that the administration supports idea generation and experimentation among the staff members of the institution. On the point of reward for risk taking and action by staff, 84 respondents said management reward for risk taking and actions among staff members is good, 69 said it is very good, 64 remained neutral, 22 said the reward for risk taking is poor and 9 said it is very poor, with only 1 respondent giving no response to the question. This therefore implies that management rewards staff for taking risk and actions. Inferences drawn from this analysis imply that the administration has been embarking on significant improvements on process innovation.

\section{Assessing the performance of University of Cape Coast Administration using marketing innovation}

From Table 4, it can be seen that all the variables under marketing innovation of UCC administration have been analysed together. In relation to the administration's use of creative communication channels, 7 respondents answered 'very poor', 11 responded with a 'poor', 48 said the administration's use of creative communication channels was neutral, 99 said it was good, 78 said it was very good and 7 respondents gave no responses at all. It can be drawn from the analysis that as 99 and 78 respondents respectively believed that the administration's use of creative communication channels is good and very good, the administration is really doing well when it comes to the use of creative communication channels to reach out to its stakeholders.

As far as the accessibility of the administration's services by stakeholders is concerned, 3 respondents said it was very poor, 11 said it was poor, 48 said it was neutral, 118 said it was good and 69 said it was very good, with 1 not giving an answer. It can be inferred that as 118 of the respondents believed the administration's services are more accessible to stakeholders, the information is credible.

Staff interaction with stakeholders was also analysed and it was found that 4 respondents believed the interaction is very poor, 13 said it is poor, 38 said it is neutral, 118 said it is good, 75 said it is very good and 2 did not provide any response. Therefore, it can be concluded that the administration is doing a good job because a higher number (118) of the respondents said the interaction with stakeholders is good. Moreover, out of the 250 respondents of this study, 3 said customer relationship management of the administration is very poor, 16 said it is poor, 47 said it is neutral, 118 said it is good, 65 said it is very good and 1 did not respond. Therefore, we can clearly infer that the customer relation management of the administration is good.
Finally, in relation to transparency of information dissemination, 8 respondents said it was very poor, 28 said it was poor, 46 said it was neutral, 93 said it was good, 71 said it was very good and 4 gave no response. The conclusion drawn from this analysis is that management's dissemination of information from the top down to the last subordinate of the administration is good.

\section{Assessing the performance of University of Cape Coast Administration using organisational innovation}

Table 5 shows that the data gathered on the firm innovation capability of the administration have been grouped into five variables. Of the respondents, 122 said that the attitude of management towards change is good, 44 said it is very good, 56 remained neutral, 20 said it is poor and 7 said it is very poor, with only 1 respondent not giving any response to the question. The analysis shows that management has a good attitude towards embracing change. On the question of the attitude of employees towards change, 115 respondents said that employees have good attitudes to change, 63 said it is very good, 49 remained neutral, 19 said it is poor and 3 said it is very poor, with only 1 respondent giving no response to the question. The analysis therefore shows that employees have a positive attitude towards change. On the question of support for teamwork, 131 respondents said that management has good support for teamwork and collaboration, 71 said it very good, 37 remained neutral, 6 said it is poor and 4 said it is very poor, with only 1 respondent giving no response to the question. The analysis therefore shows that management encourages support for teamwork and collaboration in the institution. It can also be seen from Table 5 that the administration promotes participative decision-making. About this question, the data show that 122 respondents stated a good participative decisionmaking, 67 indicated a very good participation, 41 were neutral, 11 stated a poor participation and 8 said a very poor participation, with only 1 respondent giving no response to the question.

Also on the topic of the administration investing in research and development, 94 respondents said the administration's investment in research and development is good, 98 said it is very good, 43 remained neutral, 7 said it is poor, 7 said it is very poor, with only 1 respondent not giving any response to this question. Inferences can therefore be drawn from the analysis that the administration is making a very good investment in research and development in the institution.

TABLE 4: Using only frequencies.

\begin{tabular}{|c|c|c|c|c|c|c|c|c|}
\hline Description of variables & Very poor & Poor & Neutral & Good & Very good & Total & Missing system & Total \\
\hline Using creative communication channels to reach out to stakeholders & 7 & 11 & 48 & 99 & 78 & 243 & 7 & 250 \\
\hline Accessibility of organisation's services to stakeholders & 3 & 11 & 48 & 118 & 69 & 249 & 1 & 250 \\
\hline Staff interaction with stakeholders & 4 & 13 & 38 & 118 & 75 & 248 & 2 & 250 \\
\hline Customer relationship management practices & 3 & 16 & 47 & 118 & 65 & 249 & 1 & 250 \\
\hline Transparency in information dissemination & 8 & 28 & 46 & 93 & 71 & 246 & 4 & 250 \\
\hline
\end{tabular}


TABLE 5: Using only frequencies.

\begin{tabular}{|c|c|c|c|c|c|c|c|c|}
\hline Description of variables & Very poor & Poor & Neutral & Good & Very good & Total & Missing system & Total \\
\hline Management's attitude towards change & 7 & 20 & 56 & 122 & 44 & 249 & 1 & 250 \\
\hline Employee's attitude towards change & 3 & 19 & 49 & 115 & 63 & 249 & 1 & 250 \\
\hline Support for teamwork and collaboration & 6 & 4 & 37 & 131 & 71 & 249 & 1 & 250 \\
\hline Promoting participative decision-making & 8 & 11 & 41 & 122 & 67 & 249 & 1 & 250 \\
\hline Investment in research and development (R\&D) & 7 & 7 & 43 & 94 & 98 & 249 & 1 & 250 \\
\hline
\end{tabular}

TABLE 6: Using only frequencies.

\begin{tabular}{|c|c|c|c|c|c|c|c|c|}
\hline Description of variables & Strongly agree & Agree & Neutral & Disagree & Strongly disagree & Total & Missing system & Total \\
\hline Promoting risk taking would encourage innovation & 93 & 88 & 36 & 24 & 9 & 250 & 0 & 250 \\
\hline Being innovative leads to competitive advantage & 101 & 111 & 15 & 16 & 7 & 250 & 0 & 250 \\
\hline Being innovative leads to increase market share & 96 & 105 & 25 & 18 & 5 & 249 & 1 & 250 \\
\hline Innovative capabilities promote team spirit & 97 & 110 & 21 & 12 & 9 & 249 & 1 & 250 \\
\hline Improving innovation processes increase productivity among staffs & 95 & 111 & 20 & 17 & 7 & 250 & 0 & 250 \\
\hline Innovation allows for growth and profitability of educational institutions & 90 & 111 & 24 & 19 & 5 & 249 & 1 & 250 \\
\hline Marketing innovation creates loyalty towards the institution's services & 88 & 101 & 39 & 15 & 7 & 250 & 0 & 250 \\
\hline Technological innovation makes teaching and learning convenient & 119 & 89 & 21 & 11 & 10 & 250 & 0 & 250 \\
\hline Less queueing times in terms of registration following innovation in services & 106 & 105 & 19 & 13 & 7 & 250 & 0 & 250 \\
\hline Promoting innovation reduces the risk of employee resistance to change & 98 & 100 & 35 & 11 & 6 & 250 & 0 & 250 \\
\hline
\end{tabular}

\section{Analysis of the relationship between innovative capabilities and performance of University of Cape Coast Administration}

From Table 6, concerning whether the promotion of risk taking would encourage innovation among workers, 93 respondents strongly agreed, 88 agreed, 36 were neutral, 24 disagreed and 9 strongly disagrees. This gives an indication that the administration needs to promote more risk taking among workers because the workers think if they are given this opportunity their innovative capabilities would be enhanced. With regard to the point that being innovative leads to competitive advantage, 101 respondents strongly agreed, 111 agreed, 15 were neutral, 16 disagreed and 7 strongly disagreed. This gives an impression that more workers think if the administration becomes innovative, it will lead to competitive advantage. Therefore, the administration should be more innovative in all its dealings. The researchers were able to deduce that when UCC administration adopts innovative ways, its market share is likely to increase because the analysis shows that 96 respondents strongly agreed, 105 agreed, 25 were neutral 18 disagreed and 5 strongly disagreed.

Another element investigated was that innovative capabilities promote team spirit, to which 97 respondents strongly agreed, 110 only agreed, 21 were neutral, 12 disagreed and 9 strongly disagreed. Therefore, it can be deduced that team spirit can really be boosted with the adoption of more innovations. As to whether improving innovation processes increases productivity among staff members, 95 respondents strongly agreed, 111 agreed, 20 were neutral, 17 disagreed and 7 strongly disagreed. This gives an indication that when management improves on processes to make them more innovative, productivity is likely to increase. Furthermore, 90 of the respondents strongly agreed that innovation allows for growth and profitability of educational institutions, 111 agreed with this statement, 24 were neutral, 19 disagreed and 5 strongly disagreed. It can therefore be concluded that there is a direct relationship between innovation and profitability; therefore, management should act accordingly.

In analysing whether marketing innovation increases loyalty towards the institution's products and services, 88 respondents strongly agreed, 101 agreed, 39 were neutral, 15 disagreed and 7 strongly disagreed. This shows that creative marketing will surely improve loyalty of stakeholders towards the institution. In relation to whether technological innovation makes teaching and learning more convenient, 119 respondents strongly agreed, 89 agreed, 21 were neutral, 11 disagreed and 10 strongly disagreed. This means that technology makes teaching and learning more convenient as most of the respondents either strongly agreed or agreed. Moreover, as far as there would be less queueing during registration following innovation in services, 106 respondents strongly agreed with this statement, 105 agreed, 19 were neutral, 13 disagreed and 7 strongly disagreed. This indicates that improvement in the service process will reduce queueing time during registration exercises. Finally, from the data in Table 6, 98 respondents strongly agreed that promoting innovation reduces the risk of employee resistance to change, 100 agreed with this statement, 35 were neutral, 11 disagreed and 6 strongly disagreed. This shows that most of the staff members stated that when innovation is promoted in the organisation, they will not resist reforms or changes.

\section{Conclusion}

To examine the relationship that exists between innovation and performance, certain indicators were used. Most of the respondents commented on these various indicators by strongly agreeing or just agreeing. A few of the respondents were either caught in the middle or did not agree, but their responses do not have a significant impact on the relationship. Therefore, it can be said that there is a positive or direct relationship between innovation capabilities and performance. This means that the more an organisation innovates the better it would perform, and the less it 
innovates, the poorer its performance will be. It can be concluded that there has been some innovations in UCC as both management and staff members have testified to this fact. It should not be overlooked that product and process were significantly innovated over the last 3 years than market, collaboration and firm innovations. The study further discovered that when the organisation promotes innovation, there would be high team spirits, risk taking, productivity and low resistance to change. All these would make teaching and learning more convenient and lead to higher competitive advantage and market share through the boosting of performance.

\section{Recommendation}

It is widely said that knowledge is not in the head of one person. It is of this view that the researchers of this study are making these recommendations which, if adopted and implemented by management in all educational sectors, will further boost innovative capabilities and performance as a whole. Firstly, all organisations, irrespective of their field, sector or industry have to understand that the environment in which they operate keeps on changing and therefore they have to keep on adapting in order to keep abreast with new trends. This will help them remain relevant and competitive in the ever-expanding industries so as to keep operating into the foreseeable future. Moreover, organisations have to educate their staff members on the need to keep on improving skill sets. Furthermore, organisations should listen to their stakeholders and conduct their operations in accordance with the requirements and preferences of these stakeholders. This will lead to loyalty on the part of the stakeholders to the organisation and subsequently bring about increased market shares and competitive advantage. Again, organisations should institute avenues that support idea generation and creativity so that staff members will feel free and confident to showcase their thinking and analytical abilities.

The research instrument used semi-structured questionnaires which provided room for respondents to provide certain information. This could be influenced by self-reporting of data. The study was also limited to only one institution, UCC, which could not be appropriate in generalising the findings. The researchers would therefore recommend that subsequent researchers should employ closed-ended questionnaires to collect data and also carry out the research in several institutions to provide a good basis for generalising the findings.

\section{Acknowledgements Competing interests}

The authors declare that there are no competing interests.

\section{Authors' contributions}

A.Y.A. wrote the introduction, part of the literature review and part of the methodology. R.I. wrote part of the methodology and also did the analysis. L.B. wrote part of the literature review, summary of the findings and the recommendations.

\section{Funding Information}

This research received no specific grant from any funding agency in the public, commercial, or not-for-profit sectors.

\section{Data availability statement}

Data sharing is not applicable to this article as no new data were created or analysed in this study.

\section{Disclaimer}

The views and opinions expressed in this article are those of the authors and do not necessarily reflect the official policy or position of any affiliated agency of the authors.

\section{References}

Abbing, E.R., 2010, Brand driven innovation: Strategies for development and design, Ava Publishing, Lausanne.

Adriansyah, A. \& Afiff, A.Z., 2015, 'Organizational culture, absorptive capacity, innovation performance and competitive advantage: An integrated assessment in Indonesian banking industry', The South East Asian Journal of Management 9(1), 70-86. https://doi.org/10.21002/seam.v9i1.4376

Akio, T., 2005, 'The critical assessment of the resource-based view of strategic management: The source of heterogeneity of the firm', Ritsumeikan Internationa Affairs 3, 125-150.

Akman, G. \& Yilmaz, C., 2008, 'Innovative capability, innovation strategy and marke orientation: An empirical analysis in Turkish software industry', International Journal of Innovation Management 12(01), 69-111. https://doi.org/10.1142/ S1363919608001923

Alam, l., 2006, 'Removing the fuzziness from the fuzzy front-end of service innovations through customer interactions', Industrial Marketing Management 35(4), 468-480. https://doi.org/10.1016/j.indmarman.2005.04.004

Assink, M., 2006, 'Inhibitors of disruptive innovation capability: A conceptual model', European Journal of Innovation Management 9(2), 215-233. https://doi. org/10.1108/14601060610663587

Atalay, M., Anafarta, N. \& Sarvan, F., 2013, 'The relationship between innovation and firm performance: Empirical evidence from Turkish automotive supplier industry', Procedia: Social and Behavioural Sciences 75(3), 226-235. https://doi. org/10.1016/j.sbspro.2013.04.026

Barney, J.B., 1986, 'Organizational culture: Can it be a source of sustained competitive advantage?', Academy of Management Review 11(3), 656-665. https://doi. org/10.5465/amr.1986.4306261

Barney, J.B., Ketchen Jr, D.J. \& Wright, M., 2011, 'The future of resource-based theory: Revitalization or decline?', Journal of Management 37(5), 1299-1315. https://doi. org/10.1177/0149206310391805

Bigliardi, B., 2013, 'The effect of innovation on financial performance: A research study involving SMEs', Innovation 15(2), 245-255. https://doi.org/10.5172/ impp.2013.15.2.245

Bowen, F.E., Rostami, M. \& Steel, P., 2010, 'Timing is everything: A meta-analysis of the relationships between organizational performance and innovation', Journal of Business Research 63(11), 1179-1185. https://doi.org/10.1016/j.jbusres.2009.10.014

Bowman, C. \& Ambrosini, V., 2003, 'How the resource-based and the dynamic capability views of the firm inform corporate-level strategy', British Journal of Management 14(4), 289-303. https://doi.org/10.1111/j.1467-8551.2003.00380.x

Business Dictionary, n.d., Innovation, viewed 14 April 2019, from http://www. businessdictionary.com/definition/innovation.html.

Cainelli, G., Evangelista, R. \& Savona, M., 2004, 'The impact of innovation on economic performance in services', The Service Industries Journal 24(1), 116-130. https:// doi.org/10.1080/02642060412331301162

Calantone, R.J., Cavusgil, S.T. \& Zhao, Y., 2002, 'Learning orientation, firm innovation capability, and firm performance', Industrial Marketing Management 31(6), 515-524. https://doi.org/10.1016/S0019-8501(01)00203-6

Cho, H.J. \& Pucik, V., 2005, 'Relationship between innovativeness, quality, growth profitability, and market value', Strategic Management Journal 26(6), 555-575. https://doi.org/10.1002/smj.461

Christensen, C.M. \& Overdorf, M., 2000, 'Meeting the challenge of disruptive change', Harvard Business Review 78(2), 66-77.

Cornali, F., 2012, 'Effectiveness and efficiency of educational measures: Evaluation practices, indicators and rhetoric', Sociology Mind 2(03), 255. https://doi. org/10.4236/sm.2012.23034

Das, T.K. \& Teng, B.S., 2000, 'A resource-based theory of strategic alliances', Journal of Management 26(1), 31-61. https://doi.org/10.1016/S0149-2063(99)00037-9

Deming, W.E., 1986, Out of the crisis, vol. 510, pp. 419-425, Massachusetts Institute of Technology, Centre for Advanced Engineering Study, Cambridge, MA. 
Durán-Vázquez, R., Lorenzo-Valdés, A. \& Moreno-Quezada, G.E., 2012, Innovation and CSR impact on financial performance of selected companies in Mexico, Journal of Entrepreneurship, Management and Innovation, 8(3), 5-20.

Gor, K., Mummassabba, J. \& Muturi, S., 2015, 'Evidencing enablers of innovation capabilities and their effects on organizational performance', Strategic Journal of Business \& Change Management 2(2), 2183-2196.

Gümüș, S. \& Gümüş, H.G., 2015, 'Marketing of innovation in business', Procedia-Social and Behavioral Sciences 181, 261-268. https://doi.org/10.1016/j.sbspro.2015.04.887

Gunday, G., Ulusoy, G., Kilic, K. \& Alpkan, L., 2011, 'Effects of innovation types on firm performance', International Journal of Production Economics 133(2), 662-676. https://doi.org/10.1016/j.ijpe.2011.05.014

Hesterly, B. \& Barney, J., 2008, Strategic management and competitive advantage, England, Pearson Prentice Hall.

Karabulut, A.T., 2015, 'Effects of innovation types on performance of manufacturing firms in Turkey', Procedia-Social and Behavioral Sciences 195(3), 1355-1364. https://doi.org/10.1016/j.sbspro.2015.06.322

Karim Suhag, A., Solangi, S.R., Larik, R.S.A., Lakh, M.K. \& Tagar, A.H., 2017, 'The relationship of innovation with organizational performance', International Journal of Research-Granthaalayah 5(2), 292-306.

Keskin, H., 2006, 'Market orientation, learning orientation, and innovation capabilities in SMEs: An extended model', European Journal of Innovation Management 9(4), 396-417. https://doi.org/10.1108/14601060610707849

Kothari, C.R., 2004, Research methodology: Methods and techniques, New Age International, New Delhi.

Lau, A.K., Yam, R.C. \& Tang, E.P., 2010, 'The impact of technological innovation capabilities on innovation performance: An empirical study in Hong Kong', Journal of Science and Technology Policy in China 1(2), 163-186. https://doi. of Science and Technology Policy
org/10.1108/17585521011059893

Lawson, B. \& Samson, D., 2001, 'Developing innovation capability in organisations: A dynamic capabilities approach', International Journal of Innovation Management 5(03), 377-400. https://doi.org/10.1142/S1363919601000427

Lerro, A., Linzalone, R. \& Schiuma, G., 2009, 'Modelling organisational innovation capability: A knowledge-based approach', Proceedings of the 4th IFKAD.

Likar, B., Koper, J. \& Fatur, P., 2014, 'Innovation investment and economic performance in transition economies: Evidence from Slovenia', Innovation: Management Policy \& Practice 16(1), 53-66. https://doi.org/10.5172/impp.2014.16.1.53

Lippman, S.A. \& Rumelt, R.P., 1982, 'Uncertain imitability: An analysis of interfirm differences in efficiency under competition', The Bell Journal of Economics 13(2), differences in efficiency under competition,

Meroño-Cerdan, A.L. \& López-Nicolas, C., 2013, 'Understanding the drivers of organizational innovations', The Service Industries Journal 33(13-14), 1312-1325. https://doi.org/10.1080/02642069.2013.815736

Mintzberg, H., 2008, Mintzberg on management: Inside our strange world of organizations, Free Press, New York, NY.

Montes, F.J.L., Moreno, A.R. \& Morales, V.G., 2005, 'Influence of support leadership and teamwork cohesion on organizational learning, innovation and performance: An empirical examination', Technovation 25(10), 1159-1172. https://doi. org/10.1016/j.technovation.2004.05.002

Narcizo, R.B., Canen, A.G. \& Tammela, I., 2013, 'SME's innovation capability as a resource to meet future logistical demands of Brazilian oil industry', Annals of the Faculty of Engineering Hunedoara 11(1), 157.

Ndregjoni, Z. \& Elmazi, L., 2012, 'The effects of relationship between information technology and firm innovation on firm performance: The case of Albania',
International Journal of Management Cases 14(1), 235-246. https://doi. International Journal of Manag
org/10.5848/APBJ.2012.00023

Nybakk, E. \& Jenssen, J.I., 2012, 'Innovation strategy, working climate, and financial performance in traditional manufacturing firms: An empirical analysis', International Journal of Innovation Management 16(02), 1250008. https://doi. org/10.1142/S1363919611003374
OECD, 2005, 'Oslo manual proposed guidelines for collecting and interpreting technological innovation data (Paris) of radical innovation: Insights from pharmaceuticals', Journal of Marketing 67(4), 82-102.

Odumeru, J.A., 2013, 'Innovation and organizational performance', Kuwait Chapter of Arabian Journal of Business and Management Review 2(12), 18-22. https://doi. org/10.12816/0001266

Oke, A., Walumbwa, F.O. \& Myers, A., 2012, 'Innovation strategy, human resource policy, and firms' revenue growth: The roles of environmental uncertainty and policy, and firms revenue growth: The roles of environmental uncertainty and
innovation performance', Decision Sciences 43(2), 273-302. https://doi. org/10.1111/j.1540-5915.2011.00350.x

Olsson, A., Wadell, C., Odenrick, P. \& Bergendahl, M.N., 2010, 'An action learning method for increased innovation capability in organisations', Action Learning: Research and Practice 7(2), 167-179. https://doi.org/10.1080/14767333.2010.488328

Peteraf, M.A., 1993, 'The cornerstones of competitive advantage: A resource-based view', Strategic Management Journal 14(3), 179-191. https://doi.org/10.1002/ smj.4250140303

Powell, T.C., 2001, 'Competitive advantage: Logical and philosophical considerations', Strategic Management Journal 22(9), 875-888. https://doi.org/10.1002/ smj.173

Rajapathirana, R.J. \& Hui, Y., 2018, 'Relationship between innovation capabilities, innovation type, and firm performance', Journal of Innovation \& Knowledge 3(1), 44-55. https://doi.org/10.1016/j.jik.2017.06.002

Saunders, M., Lewis, P. \& Thornhill, A., 2016, Research methods for business students, 7th edn., Pearson Education Ltd, Harlow.

Saunila, M., Pekkola, S. \& Ukko, J., 2014, 'The relationship between innovation capability and performance: The moderating effect of measurement', International Journal of Productivity and Performance Management 63(2), 234-249. https:// doi.org/10.1108/IJPPM-04-2013-0065

Serdyukov, P., 2017, 'Innovation in education: What works, what does not, and what to do about it?', Journal of Research in Innovative Teaching \& Learning 10(1) 4-33. https://doi.org/10.1108/JRIT-10-2016-0007

Stegerean, R. \& Gavrea, C., 2010, 'Innovation and development-criteria for organizational performance', Managerial Challenges of the Contemporary Society. Proceedings, 202(1), 202-205.

Wei, L.Q., Liu, J. \& Herndon, N.C., 2011, 'SHRM and product innovation: Testing the moderating effects of organizational culture and structure in Chinese firms', The International Journal of Human Resource Management 22(01), 19-33. https:// doi.org/10.1080/09585192.2011.538965

Wernerfelt, B., 1984, 'A resource-based view of the firm', Strategic Management Journal 5(2), 171-180. https://doi.org/10.1002/smj.4250050207

Wolff, J.A. \& Pett, T.L., 2006, 'Small-firm performance: Modeling the role of product and process improvements', Journal of Small Business Management 44(2), 268-284. https://doi.org/10.1111/j.1540-627X.2006.00167.x

Yen, Y., 2013, 'The impact of bank's human capital on organizational performance: How innovation influences performance', Innovation: Management, Policy \& Practice 15(1), 112-128. https://doi.org/10.5172/impp.2013.15.1.112

Yu, D. \& Hang, C.C., 2010, 'A reflective review of disruptive innovation theory', International Journal of Management Reviews 12(4), 435-452. https://doi. org/10.1111/j.1468-2370.2009.00272.x

Zawislak, P.A., Cherubini Alves, A., Tello-Gamarra, J., Barbieux, D. \& Reichert, F.M. 2012, 'Innovation capability: From technology development to transaction capability', Journal of Technology Management \& Innovation 7(2), 14-27. https:// doi.org/10.4067/S0718-27242012000200002

Zhou, K.Z., Yim, C.K. \& Tse, D.K., 2005, 'The effects of strategic orientations on technology-and market-based breakthrough innovations', Journal of Marketing 69(2), 42-60. https://doi.org/10.1509/jmkg.69.2.42.60756 